\title{
CARTA DA ASIHVIF NOSSA CARTA
}

\section{Preâmbulo: a carta: o que ela é, suas funções, seus usos¹.}

1.1 A Carta: o que ela é

Trata-se de um documento que constitui um marco. Ela atesta a existência de uma reflexão sobre nossas referências comuns, axiológicas, epistemológicas e metodológicas. Ela dá parâmetros éticos para as práticas da Associação.

\subsection{A Carta: suas funções}

Suas funções são triplas: identitária, constituinte, referencial. Enquanto enunciado de princípios que orientam a prática das narrativas de vida, a Carta reúne formadores, pesquisadores e práticos numa coletividade instituída.

Além desta identidade interna da Associação, a Carta apresenta a especificidade da ASIHVIF e assegura a credibilidade no amplo campo das práticas da abordagem biográfica.

1.3 A Carta: seus usos

A carta não é um instrumento de normalização das práticas dos membros da Associação. Ela não tem também por objeto ser a referência ética dos narradores. Seguramente, a Carta constitui uma referência comum para o questionamento dos membros da ASIHVIF.

Nesse sentido, para aderir à ASIHVIF, solicita-se de todo candidato que subscreva as proposições da Carta e que contribua para sua evolução. A Carta torna-se objeto de um debate periódico.

\section{O objeto da Associação}

2.1 A finalidade da ASIHVIF é desenvolver práticas de história de vida por meio da narrativa de vida, no âmbito da formação, da pesquisa e da intervenção.

Trata-se de um procedimento que coloca, no centro, o sujeito narrador, enquanto aquele que define seu objeto de busca e desenvolve um projeto de compreensão de si para si e pela mediação do outro.

2.2 A perspectiva que orienta, media e apóia as práticas da narrativa de vida é a emancipação pessoal e social do sujeito.

Entende-se por "emancipação" a ação que tende a substituir uma relação de assujeitamento por uma relação de igualdade.

Enquanto prática de formação, a narrativa de vida permite ao sujeito apreender seus objetivos existenciais no seio da coletividade.

Enquanto método de pesquisa qualitativa, a narrativa de vida constitui um procedimento inovador em relação aos modelos de pesquisa mais clássicos.

1 Revista após a Assembleia Geral extraordinária de 19/10/2002, com base na versão produzida após o simpósio realizado em Paris em 1o e 2 de junho de 2002. 
Enquanto prática de intervenção, a narrativa de vida permite ao sujeito, com base numa explicitação de seu percurso de vida, dispor dos meios necessários à tomada de consciência reflexiva e crítica, visando situar-se como ator social num projeto de ação mais lúcida e mais pertinente.

2.3. Este procedimento autobiográfico tem então uma tripla função: a de pesquisa (produção de conhecimentos), a de formação e a de intervenção (configuração de si numa perspectiva de ação social).

2.4. Os efeitos da experiência de uma prática de narrativa de vida são múltiplos e essencialmente relativos à singularidade das pessoas que se engajam nessa prática. Eles podem ser de ordem epistêmica (um ganho de saber quanto ao seu passado, seu futuro, suas potencialidades e restrições atuais), identitária (segundo a variedade das dinâmicas possíveis), e também terapêutica.

2.5. Uma das maiores consequências da maneira como a Associação define seu objeto é recusar a separação entre teoria e prática. Isso concerne à distribuição hierarquizada dos lugares do pesquisador, do prático e do sujeito narrador (indivíduo ou grupo). A Associação entende sua substituição por uma relação dialética, na qual as teorias interrogam as práticas e vice-versa. Ela espera, por conseguinte, um efeito de renovação, ao mesmo tempo, no campo das práticas de pesquisa, de formação e de intervenção, e no campo da teorização, mais especificamente, na educação permanente e na formação de adultos.

\section{A relação do formador, do pesquisador e do mediador com o narrador (individual ou coletivo)}

3.1. Uma humanidade partilhada

A produção narrativa em grupo requer um clima de confiança mútua, com base no reconhecimento da singularidade do sujeito e a abertura para a alteridade, vivida como uma humanidade partilhada.

\subsection{Uma parceria}

A construção de um projeto de pesquisa-formação-intervenção pela narrativa de vida apóiase, por um lado, sobre a explicitação da oferta feita pelo formador, o pesquisador ou o prático e, por outro lado, sobre a expressão para os narradores potenciais de suas intenções e de suas expectativas. Os narradores são então parceiros desde o início do procedimento. A parceria fundamenta-se no reconhecimento da autonomia do narrador na construção de seu testemunho e no dever de sigilo por parte de quem acompanham o processo narrativo em cada uma de suas etapas (produção, socialização, análise e interpretação). É assim que o narrador permanece o sujeito autor ao mesmo tempo de sua narrativa e do sentido que ele lhe atribui. 0 terceiro-acompanhante (formador, pesquisador ou prático) participa de uma coprodução do sentido quando ele entrecruza a narrativa com sua questão de pesquisa e comunica as ressonâncias que nele desperta a narrativa. 


\subsection{Um acordo contratual}

O engajamento concreto dos parceiros neste procedimento traduz-se por uma contratualidade explícita. Ela diz respeito notadamente às modalidades de realização e às cláusulas que protegem a confidencialidade e os direitos de autoria dos narradores.

\subsection{Uma prática contextualizada}

A abordagem biográfica pode ser praticada em contextos institucionais variados, cujas características devem ser consideradas, por um lado, na apreciação da oportunidade de realização da abordagem biográfica e, por outro lado, na construção do projeto concreto.

\section{As exigências da função de formador, de pesquisador ou de prático com as narrativas de vida}

4.1. Cabe ao formador, ao pesquisador ou ao prático, que trabalham com narrativas de vida, fazer uma análise crítica e uma avaliação de sua própria prática. Essa última se realiza, por um lado, na interação com os narradores a propósito do procedimento autobiográfico que ele acompanha e, por outro lado, na partilha de sua própria experiência por ocasião das práticas de co-animação e sessões de análise de práticas, entre pares, no seio da Associação. Essas trocas revestem-se de um caráter de conviviabilidade, tanto quanto possível, livres de relações hierárquicas.

4.2. A Associação solicita que o futuro formador tenha vivenciado, ele mesmo, a experiência de um procedimento autobiográfico.

4.3. A Associação não privilegia nenhum referencial teórico em particular. Ela valoriza o recurso a teorias e métodos plurais e favorece, por exemplo, os debates sobre essas questões na apresentação de produções escritas dos membros.

\section{Aberturas}

A Associação entende implementar um certo número de campos de pesquisa. A guisa de exemplo, podem ser citadas:

- A dimensão "estética" da formação-pesquisa-intervenção das histórias de vida;

- A inscrição da perspectiva antropoformativa nas histórias de vida;

- A dimensão intercultural das histórias de vida;

Fonte: http://www.asihvif.com/1/upload/charte.pdf

Tradução Maria da Conceição Passeggi 